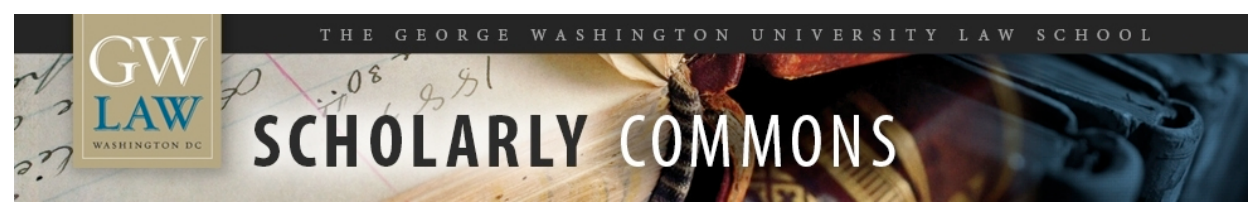

GW Law Faculty Publications \& Other Works

Faculty Scholarship

2007

\title{
A New WTO Paradigm for Trade and the Environment
}

Steve Charnovitz

George Washington University Law School, scharnovitz@law.gwu.edu

Follow this and additional works at: https://scholarship.law.gwu.edu/faculty_publications

Part of the Law Commons

\section{Recommended Citation}

Steve Charnovitz, A New WTO Paradigm for Trade and the Environment, 11 Singapore Yearbook of Int'I L. 15 (2007).

This Article is brought to you for free and open access by the Faculty Scholarship at Scholarly Commons. It has been accepted for inclusion in GW Law Faculty Publications \& Other Works by an authorized administrator of Scholarly Commons. For more information, please contact spagel@law.gwu.edu. 


\title{
A NEW WTO PARADIGM FOR TRADE AND THE ENVIRONMENT
}

\author{
by STeve Charnovitz*
}

\begin{abstract}
This article provides an overview of the "trade and environment" interface in the World Trade Organization (WTO) and proposes new paradigm for making progress. In doing so, the article reviews recent developments in WTO adjudication and negotiations and examines the institutional interplay of international trade and biosafety with particular reference to the Cartagena Protocol on Biosafety. ${ }^{1}$ The article also points to several pro-environmental initiatives that could be taken by the WTO.

The article is divided into five parts. Part I provides a brief review of the history of environment linkage in trade policy, beginning in 1923. Part II offers a Tour d'Horizon of WTO rules and policies with implications for the environment. Part III looks at the environmental components of the WTO's Doha Round negotiations. Part IV uses the example of biosafety to show why the traditional paradigm of the WTO as a trade-only agency needs to be replaced by a new paradigm. Part V concludes.
\end{abstract}

\section{The Trade-Environment Linkage in Historical Perspective}

At its origins in the 1920 s, the trading system sought to avoid interfering with national health and environmental policy measures. The first multilateral treaty on trade, the Customs Simplification Convention of $1923,{ }^{2}$ contained a provision stating that the disciplines of the treaty did not "prejudice the measures which contracting parties may take to ensure the health of human beings, animals or plants". ${ }^{3}$ The next major multilateral trade treaty was the Trade Prohibitions Convention of $1927^{4}$ which sought to discipline import and export prohibitions. The Convention included an exception for "prohibitions or restrictions imposed for the protection of human health and for the protection of animals and plants against disease, insects and harmful parasites". 5 After the treaty was negotiated, there was some concern about whether this exception was sufficiently capacious. Therefore, a Protocol to the Convention was used to clarify that this exception "also refers to measures taken to preserve them [animals and plants] from degeneration or extinction and to measures taken against harmful seeds, plants, parasites and animals". ${ }^{6}$ The Protocol makes clear that even by 1927 , the international community was aware of the implications of trade rules for biodiversity and biosafety.

* Thanks to Aaron Cosbey and Don Regan for helpful comments. An earlier version of this article was prepared for a United Nations University project on Institutional Interplay in Biosafety and Trade.

1 Cartagena Protocol on Biosafety to the Convention on Biological Diversity, 29 January 2000, 39 I.L.M. 1027; Convention on Biological Diversity, 5 June 1992, 31 I.L.M. 818.

2 International Convention Relating to the Simplification of Customs Formalities, 3 November 1923, 30 L.N.T.S. 371.

3 Ibid., art. 17.

4 International Convention for the Abolition of Import and Export Prohibitions and Restrictions, 8 November 1927, 97 L.N.T.S. 393.

5 Ibid., art. 4.4.

6 Protocol, ibid., ad art. $4(\mathrm{a})$. 
After World War II, when leading governments negotiated both the General Agreement on Tariffs and Trade ${ }^{7}$ and the Charter of the International Trade Organization, ${ }^{8}$ there were a sufficient number of multilateral environmental agreements in place with specific trade obligations such that the drafters of the Charter took care to include a general exception for measures "taken in pursuance of any inter-governmental agreement which relates solely to the conservation of fishery resources, migratory birds or wild animals ...". 9 The immediate post-war period had been an active time for international environmental policymaking, and saw the negotiation of the Whaling Convention of $1946,{ }^{10}$ the Fishing Nets Convention of $1946,{ }^{11}$ the Pan American Nature Protection Convention of $1948,{ }^{12}$ and the organic act of the International Union for the Conservation of Nature and Natural Resources of $1948 .{ }^{13}$ Thus, the architects of the multilateral trading system were aware of certain environmental challenges and of the need to keep emerging trade policies compatible.

Unfortunately, the Charter of the International Trade Organization failed to go into force. In its place, the GATT (as amended) remained the organic law of the trading system until the WTO came into being in 1995. The GATT eventually assumed the role of an international organization. But the GATT lacked the duty of coordinating with the United Nations contemplated in the 1948 Charter. ${ }^{14}$

Environmental issues began to bump up against the GATT in the early 1970s. As an intellectual contribution to the 1972 U.N. Stockholm Conference on the Human Environment, the GATT Secretariat prepared a report on "Industrial Pollution Control and International Trade". ${ }^{15}$ In the same period, officials in the GATT Secretariat gave technical advice to the drafters of the 1973 Convention on International Trade in Endangered Species of Wild Fauna and Flora ${ }^{16}$ on how to make its trade obligations GATT-consistent. ${ }^{17}$ In 1971, the GATT established a standby Group on Environmental Measures and International Trade. This GATT Group did not meet for 20 years-showing in retrospect how interest in trade and environment waned after the Stockholm Conference.

By the early 1990 s, pressure grew within the GATT to convene the Group and there was growing pressure from nongovernmental organizations (NGOs) for the trading system to be more accountable. Several events in the early 1990 s contributed to a concern that the GATT might be acting in an environmentally-blind way. The GATT Group met intermittently over the next couple of years until it was replaced in 1995 by the WTO Committee on Trade and Environment. The Committee's efforts have contributed to a better understanding of those intersecting policies and to better coordination of decision-making at the national level. ${ }^{18}$

30 Oct 1947, 55 U.N.T.S. 194 [The current text of GATT 1994 can be found on the WTO website].

B Havana Charter for an International Trade Organization, 24 March 1948, 55 U.N.T.S. 187, online: WTO <http://www.wto.org/english/docs_e/legal_e/prewto_legal_e.htm>.

9 Ibid., art. $45(1)(\mathrm{a})(\mathrm{x})$. (not in force).

10 International Convention for the Regulation of Whaling, 2 Dec 1946, 161 U.N.T.S. 72.

11 Convention for the Regulation of the Meshes of Fishing Nets and the Size Limits of Fish, 5 April 1946, 231 U.N.T.S. 199.

12 The Convention on the World Meteorological Organization, 11 October 1947, 77 UNTS 143.

13 Statutes of the International Union for the Conservation of Nature and Its Resources. 5 October 1948. BZTS $1975 / 21$.

14 Supra note 8 , art. 86.

15 GATT, Industrial Pollution Control and International Trade, GATT Studies in International Trade No. 1 (Geneva: GATT Secretariat, 1971).

163 March 1973, 993 U.N.T.S. 243 [CITES].

17 Robert Boardman, International Organization and the Conservation of Nature (Bloomington: Indiana University Press, 1981) at 89-92.

13 Gregory C. Shaffer, "The World Trade Organization Under Challenge: Democracy and the Law and Politics of the WTO's Treatment of Trade and Environment Matters" (2001) 25(1) Harv. Envtl. L. Rev. 1. 
The scholarly output on "trade and the environment" is extensive and includes contributions from lawyers, economists, international relations specialists, scientists, etc. ${ }^{19}$ In this short article, it is not possible to summarize that literature or to detail the many ways in which trade flows affect the environment ${ }^{20}$ or the ways in which environmental measures may restrict trade. Instead, Parts II and III move directly to discuss the trends within the WTO that may influence environmental governance.

19 Some of the mainstream studies and collections include: Kym Anderson \& Richard Blackhurst, eds., The Greening of World Trade Issues (Hertfordshire: Harvester Wheatsheaf, 1992); Konrad von Moltke, "'The Last Round: The General Agreement on Tariffs and Trade in Light of the Earth Summit” (1993) 23 Envtl. L. 519; Richard Blackhurst et al., (1994) Trade and Sustainable Development Principles (Winnipeg: International Institute for Sustainable Development, 1994). The Principles were developed by a nine-person expert group that included Konrad von Moltke, as well as others, such as David Runnalls and Janine Ferretti, who were to make important contributions to the trade and environment field; Daniel C. Esty, Greening the GATT (Washington; D.C.: Institute for International Economics, 1994); Konrad von Moltke, "The World Trade Organization and the Environment: What Must Change" (Paper presented to the PSIO, 1996) PSIO Occasional Papers (Geneva: Graduate Institute of International Studies, 1996) 1; Per G. Fredriksson ed., Trade, Global Policy and the Environment (Washington, D.C.: World Bank, 1999); Barrett, Scott et al., "Special Issue: Trade and Environment" (2000) 5(4) Environment and Development Economics 341; Peider Könz ed., Trade, Envirörment and Sustainable Development: Views from Sub-Saharan Africa and Latin America. A Reader (Tokyo: United Nations University Press, 2000); W. Bradnee Chambers ed., Inter-linkages. The Kyoto Protocol and the International Trade and Investment Regimes (Tokyo: United Nations University Press, 2001); Daniel C. Esty, "Bridging the Trade-Environment Divide" (2001) 15(3) Journal of Economic Perspectives 113; José María Figueres Olsen $e t$ al., "Trade and Environment at the World Trade Organization: The Need for a Constructive Dialogue" in Gary P. Sampson ed.; The Role of the World Trade Organization in Global Governance (Tokyo: United Nations University Press, 2001); P.K. Rao, Environmental Trade Disputes at the WTO (Lawrenceville, NJ: Pinninti Publishers, 2001); Sara Dillon, "A Farewell to 'Linkage': International Trade Law and Global Sustainability Indicators" (2002) 55 Rutgers L. Rev. 87; Gary P. Sampson \& W. Bradnee Chambers eds., Trade, Environment, and the Millennium, $2^{\text {nd }}$ ed. (Tokyo: United Nations University Press, 2002); Richard H. Steinberg, The Greening of World Trade Law (Lanham, MD: Rowman \& Littlefield Publishers, 2002); Lori M. Wallach, "Accountable Governance in the Era of Globalization: The WTO, NAFTA, and International Harmonization of Standards" (2002) 50(4) U. Kan. L. Rev. 823; Jochem Wiers, Trade and Environment in the EC and the WTO (Groningen, The Netherlands: Europa Law Publishing, 2002); Sanford E. Gaines, "The Problem of Enforcing Environmental Norms in the WTO and What To Do About It" (2003) 26 Hastings Int'l \& Comp. L. Rev. 321; Kanami Ishibashi, "Environmental Measures Restricting the Waste Trade", in Alexandre Kiss et al. eds., Economic Globalization and Compliance with International Environmental Agreements (The Hague: Kluwer Law International, 2003) 59; Donald McRae, "Trade and the Environment: Competition, Cooperation or Confusion?", (2003) 41(3) Alta. L. Rev. 745; Aaron Cosbey, Lessons Learned on Trade and Sustainable Development (Winnipeg: International Institute for Sustainable Development, 2004); Aaron Cosbey, A Capabilities Approach to Trade and Sustainable Development. Using Sen's Conception of Development to Re-Examine the Debates (Winnipeg: International Institute of Sustainable Development, 2004); John H. Knox; "The Judicial Resolution of Conflicts Between Trade and the Environment" (2004) 28 Harv. Envtl. L. Rev. 1; Kuei-Jung Ni, "Redefinition and Elaboration of an Obligation to Pursue International Negotiations for Solving Global Environmental Problems in Light of the WTO Shrimp/Turtle Compliance Adjudication Between Malaysia and the United States" (2001) 14(1) Minn. J. Global Trade 111. Some recent studies include: Howard F. Charg, "Environmental Trade Measures, the Shrimp-Turtle Rulings, and the Ordinary Meaning of the Text of the GATT" (2005) 8 Chapman L. Rev. 25; David M. Driesen, "What is Free Trade? The Rorschach Test at the Heart of the Trade and Environment Debate" in E. Kwan Choi and James C. Hartigan eds., Handbook of International Trade, Vol. 2 (Malden, MA: Blackwell Publishing, 2005) 5; Gary Sampson \& John Whalley eds., The WTO, Trade and the Environment, Cheltenham (U.K: Edward Elgar, 2005); UNEP, The Trade and Environmental Effects of Ecolabels: Assessment and Response, (2005), online: UNEP <http://www.unep.ch/etb/publications/Ecolabelpap141005f.pdf>; Simonetta Zarrilli, "International Trade in GMOs and GM Products: National and Multilateral Legal Frameworks" in Policy Issues in International Trade and Commodities Study Series No. 29 (Geneva: UNCTAD, 2005); Anupam Goyal, The WTO and International Environmental Law (Oxford: Oxford University Press, 2006).

20 With regard to trade flows, Copeland and Taylor argue that the scale, technique, and compositional changes from trade can help to control pollution (Brian R. Copeland \& M. Scott Taylor, Trade and the Environment. Theory and Evidence (Princeton: Princeton University Press, 2003). 


\section{The Environment in WTO Law and Policy}

The:WTO's attention to the environment starts at the beginning of the WTO treaty. In the Preamble to the Agreement Establishing the WTO, ${ }^{21}$ the parties note that they act to establish the WTO

... recognizing that their relations in the field of trade and economic endeavour should be conducted with a view to raising standards of living ... while allowing for the optimal use of the world's resources in accordance with the objective of sustainable development, seeking both to protect and preserve the environment and to enhance the means for doing so in a manner consistent with their respective needs and concerns at different levels of economic development...". ${ }^{22}$

In the U.S.-Shrimp case, ${ }^{23}$ in 1998, the WTO Appellate Body drew attention to this provision and used it to help interpret the general exceptions in GATT Article XX. ${ }^{24}$ The appellators famously stated that the Preamble "informs". all of the WTO trade agreements and "explicitly acknowledges" the objective of sustainable development" ". 25 In reference to this and other language in Shrimp, Professor John Jackson calls the decision "a constitutional door opener for approaches that require a broader perspective than just the four corners of the very extensive GATT/WTO treaty language". 26

Because of the controversy surrounding the Shrimp case and the fact that the jurists ruled against the U.S. conservation measure being challenged, the Appellate Body included a coda at the end of its holdings to underscore what it had not decided.

We have not decided that the protection and preservation of the environment is of no significance to the Members of the.WTO. Clearly, it is: We have not decided that the sovereign nations that are Members of the WTO cannot adopt effective measures to protect endangered species, such as sea turtles. Clearly, they can and should. And we have not decided that sovereign states should not act together bilaterally, plurilaterally or multilaterally, either within the WTO or in other international fora, to protect endangered species or to otherwise protect the environment. Clearly, they should and do. ${ }^{27}$

Two features of this decision should be noted. First, the Appellate Body says that states "should" adopt effective measures to protect endangered species.. That holding seems normative, but can perhaps be understood as merely a rhetorical flourish. "Second, the Appellate Body seems to be suggesting that states can and should act together plurilaterally or multilaterally within the WTO to protect endangered species or to otherwise protect the environment. That holding is harder to overlook. It has to reflect an assumption by the Appellate Body that such collective action within the WTO would be consistent with the WTO's competence.

21 April 15, 1994, online: WTO <http:/www.wto.org/english/docs_e/legal_e/04-wto_e.htm>.

22 Ibid.

23 United States-Import Prohibition of Cértain Shrimp and Shrimp Products' (1998), WTO Doc. WT/DS58/AB/R (Appellate Body Report) [Shrimp].

24 Supra note 7 , art. XX.

25 Supra note 23 at para. 129 (internal footnote deleted); see also paras. 153, 155.

26 John H. Jackson, “Justice Feliciano' and the WTO Environmental Cases: Laying the Foundations of a 'Constitutional Jurisprudence' with Implications for Developing Countries" in Steve Charnovitz, Debra P. Steger \& Peter van den Bössche eds., Law in the Science of Human Dignity (Cambridge: Cambridge University Press, $2005) 29$ at 40.

27 Supra note 23 at para. 185. 
In the follow-up compliance dispute in Shrimp, the panel held that "sustainable development is one of the objectives of the WTO Agreement". ${ }^{28}$ This remarkable statement drew no criticism when the WTO Dispute Settlement Body adopted the panel decision. Another breathtaking statement in that panel report was its call to the two disputing parties "... to cooperate fully in order to conclude as soon as possible an agreement which will permit the protection and conservation of sea turtles to the satisfaction of all interests involved and taking into account the principle that States have common but differentiated responsibilities to conserve and protect the environment". ${ }^{29}$ To my knowledge, no WTO member government criticized this statement by the panel as being ultra vires the purpose of the WTO.

In its 1998 Shrimp ruling, the Appellate Body took note of the Uruguay Round Decision on Trade and Environment, and held that this Decision can "help to elucidate the objectives of WTO Members with respect to the relationship between trade and the environment". ${ }^{30}$ In particular, the Appellate Body quoted from the 1994 terms of reference for the Committee on Trade and Environment, which include whether to make recommendations for modifications of WTO provisions as regards, in particular:

... the need for rules to enhance positive interaction between trade and environmental measures, for the promotion of sustainable development, with special consideration to the needs of developing countries, in particular those of the least developed among them; and ... the avoidance of protectionist trade measures, and the adherence to effective multilateral disciplines to ensure responsiveness of the multilateral trading system to environmental objectives set forth in Agenda 21 and the Rio Declaration, in particular Principle $12 ; \ldots{ }^{31}$

This Committee mandate shows that governments agreed to assess whether the WTO should have provisions to achieve positive interaction between trade and the environment, to promote sustainable development, and to ensure WTO responsiveness to international environmental objectives. How serious governments were in 1994 in setting up the Committee is debatable, but one can hardly doubt that environment is now part of the WTO's mandate.

The WTO treaty contains 24 covered agreements and other understandings that are part of a single undertaking. Many of these legal texts contain provisions relating to the environment. The WTO Secretariat boasts of them as the WTO's "green provisions", but does not define that term. ${ }^{32}$

In thinking about what renders a WTO provision green (i.e., pro-environmental), one should recall the range of environmental policy instruments that governments use-to wit, regulations, taxes, standards, labelling, subsidies and other technology incentives, trade controls, allocation and clarification of property rights, reporting and accountability for private actors, and environmental diplomacy. These instruments may be used to regulate public health, manage natural resources and biodiversity, and otherwise maintain the availability and quality of public goods. An international rule that commits governments to the use of such instruments to safeguard the environment can reasonably be considered "green". In contrast, an international rule that prevents governments from using these instruments is the antithesis of "green".

Although WTO law does not directly dictate what the goals of a government's environmental policy should be or what instruments can be used, the scope of WTO law is broad enough to influence those choices. First, WTO law removes policy space from governments

28 United States-Import Probibition of Certain Shrimp and Shrimp Products (Recourse to Article 21.5 of the DSU by Malaysia) (2001), WTO Doc. WT/DS58/R/W at para. 5.54 (Panel Report).

29 Ibid. at para. 7.2 (footnote deleted referring to Principle 7 of the Rio Declaration).

30 Supra note 23 at para. 154.

31 Supra note 23 at para. 154.

32 WTO, "The environment: a new high profile", online: WTO <http://www.wto.org/english/thewto_e/whatis_e/ tif_c/bcy2_c.htm>. 
to use environmental measures in particular ways. Second, WTO law may sometimes promote better environmental and health outcomes than would occur in the absence of the WTO.

The next section provides an analytical overview of the environmental provisions present in WTO law, and some that are: notably absent. WTO law contains three founts of rulemaking - pertaining to trade in goods, trade in services, and trade-related intellectual property. The three founts are subsumed within the umbrella WTO treaty and all share a common dispute settlement mechanism.

\section{A. Trade in Goods}

As a WTO panel noted, environmental standards can have an impact on trade. ${ }^{33}$ This potential trade impact brings environmental law under the supervision of the WTO. In applying its environmental or health policy to imported products, a government must ordinarily follow the principles of most-favoured-nation (MFN) and national treatment. MFN treatment means that an imported product from a WTO member is not to be treated less favourably than a like imported product from any other country. National treatment means that an imported product is not to be treated less favorably with respect to a regulation or tax than the like domestic product is treated. Although the WTO Secretariat has taken the position ${ }^{34}$ that regulations and taxes cannot be hinged on the externalities of production, ${ }^{35}$ no authority exists in WTO law for that proposition, and many environmentalists hope that trade law will be flexible enough to accommodate such process-related measures. ${ }^{36}$ Another major trade rule for imported products is that quantitative restrictions such as import bans are generally prohibited. This rule would seem to apply to import bans dictated by a multilateral environmental agreement (MEA), but this issue has not yet arisen in dispute settlement.

If a government has a good reason for violating MFN, national treatment, or the pro-" hibition of import (or export) bans, the government may be able to defend its measure by qualifying for one of the exceptions in GATT Article XX. ${ }^{37}$ The WTO Secretariat sometimes forgets this. ${ }^{38}$ Two exceptions are most applicable to environmental policy: Articles $\mathrm{XX}(\mathrm{b})$ for measures "necessary to protect human, animal or plant life or health" 39 and $\mathrm{XX}(\mathrm{g})$ for measures "relating to the conservation of exhaustible natural resources if such measures are made effective in conjunction with restrictions on domestic production or consumption". ${ }^{40}$ Both exceptions are subject to the requirement in the Article XX chapeau that "such measures are not applied in a manner which would constitute a means of arbitrary or unjustifiable discrimination between countries where the same conditions

33 Turkey-Restrictions on Imports of Textile and Clothing Products (1999), WTO Doc. WT/DS34/R at para. 9.120 (Panel Report).

34 According to the WTO Secretariat, "trade restrictions cannot be imposed on a product purely because of the way it has been produced" (WTO, "The environment: a new high profile", available from http:/huwwivituto.org/ englishithetuto_elwhatis_eltif_elbey2_e.htm.).

35 Process or production related measures are sometimes referred to as "PPMs".

36 In one environmental dispute, origin-based discrimination related to the environmental production process was upheld. Supra note 23 at para. 152 (provisional justification under GATT exception).

37 Supra note 7 , art XX.

38 According to the WTO Secretariat, "WTO Members are free to adopt national environmental protection policies provided that they do not discriminate between imported and domestically-produced products (national treatment principle), or between like products imported from different trading partners (most-fayoured-nation clause)" (WTO, Trade and Enviroment at the WTO (Geneya: WTO, 2004) at 7.). This point is untrue as it ignores GATT Article XX which may permit discrimination that meets the conditions in Article XX's chapeau.

39 Supra note 7 , art. $\mathrm{XX}(\mathrm{b})$.

40 Supra note 7 , art. XX(g). 
prevail, or a disguised restriction on international trade ...".41 Whether these exceptions extend to environmental resources outside the importing country remains unresolved in WTO jurisprudence. ${ }^{42}$

The trend in Article $\mathrm{XX}(\mathrm{b})$ caselaw is for a more stringent interpretation of the term "necessary" than existed in the GATT era. In the Korea-Beef case, ${ }^{43}$ the Appellate Body suggested that for a measure to be "necessary", it must pass a "weighing and balancing process" in which a panel has to consider three "factors": (1) the importance of the value protected by the law or regulation, (2) the contribution made by the contested measure to the end pursued, and (3) the restrictive impact of the measure on imports. ${ }^{44}$ Yet also in the case, the Appellate Body stated that this weighing and balancing process is comprehended in the determination of whether there is a WTO-consistent (or less-WTO-inconsistent) measure available which the government could reasonably employ to achieve its own policy goal. In trade disputes since then, the Appellate Body continued to refer to the weighing and balancing test. ${ }^{45}$ This test was not part of GATT's trade jurisprudence for Article XX which did not at any time suggest that a government's chosen policy measure might have to give way to a less trade-restrictive alternative. ${ }^{46}$

The new approach has troubling implications for national environmental policy. One problem is that the test can necessitate inter-country comparisons of utility in weighing, for example, environmental protection in one country versus the trade of another. Although national courts will sometimes weigh environment versus commerce, having an multilateral court do inter-country weighing is unusual.

The most recent WTO panel decision under Article XX(b) came in Brazil-Retreaded Tyres, a dispute brought against Brazil by the European Communities (EC). ${ }^{47}$ At issue is Brazil's import ban on retreaded tyres. The measure was imposed by Brazil to prevent the accumulation of waste tyres and thus to avoid the risks of fire and mosquito-borne illnesses. The panel held that Brazil's measure violates the GATT and did not qualify for the Article $\mathrm{XX}(\mathrm{b})$ exception. At the time of writing, it remains open to both parties to appeal the decision.

The panel's adjudication of Article XX(b) follows the jurisprudence of GATT exceptions articulated by the Appellate Body. The Tyres panel considered whether there was a measure less restrictive of trade that could qualify as an alternative measure for Brazil, and then concluded that it saw none. Therefore, Brazil's measure met the Article XX(b) "necessary" test. Where Brazil failed was the Article XX chapeau. Specifically, the panel found that the import ban on EC retreaded tyres was "arbitrary or unjustifiable discrimination" 48 because some importers in Brazil had been successful in Brazilian courts (over the opposition of Brazil's regulators) in gaining judicial injunctions to allow some used tyre imports. Along the same lines, the panel found that there was a "disguised restriction" on trade because the

41 Supra note 7 , art. XX.

42 Supra note 23, para. 133.

43 Korea-Measures Affecting Imports of Fresh, Chilled and Frozen Beef (2001), WTO Doc. WT/DS161,169/ $\mathrm{AB} / \mathrm{R}$ (Appellate Body Report). This is an Article XX(d) case. The Appellate Body uses the same interpretive approach for Article XX(b) as for Article XX(d).

44 Ibid., at paras. 163-166 (regarding Article XX(d)).

45 The Appellate Body applied this test to health measures in the Asbestos case (European CommunitiesMeasures Affecting Asbestos and Asbestos-containing Products (2001), WTO Doc. WT/DS135/AB/R (Appellate Body Report)) and has confirmed it twice since then regarding Article XX(d), most recently in its April 2005 decision in the Dominican Republic-Cigarettes case (Dominican Republic-Measures Affecting the Importation and Internal Sale of Cigarettes (2005), WTO Doc. WT/DS302/AB/R (Appellate Body Report). The Appellate Body applied the same approach to adjudication of the "necessary" test in the Services Agreement exceptions.

46 There were some pre-WTO Article XX decisions regarding "necessary" suggesting that a government's chosen policy measure might have to give way to a less GATT-inconsistent alternative.

47 Brazil-Measures Affecting Imports of Retreaded Tyres (2007), WTO Doc. WT/DS332/R (Panel Report).

48 Ibid. 
import ban on retreaded tyres has "operated to the benefit of domestic retreaders, while the fulfilment of the purpose for which it [the import ban] has been justified is being significantly undermined." 49 Given the facts of the case, these conclusions seem warranted. The holding is noteworthy, however, as the first in WTO (or GATT) jurisprudence to find an independent violation of this prong of the chapeau.

Perhaps the most interesting feature of this dispute was the anti-environmental positions taken by the EC. Astonishingly, the EC argued that "measures intended to protect the environment as such are not covered by Article XX(b) ..." 50 In addition, the EC argued unsuccessfully that there was not a sufficient link between the harmful effects of tyre fires and an accumulation of tyre imports into Brazil. ${ }^{51}$

In addition to qualifying for a GATT Article XX General Exception, governments may also derogate from the MFN requirement through three kinds of preferential trade arrangements-customs unions, free trade agreements (FTAs), and the generalized system of preferences (GSP) for developing countries. The establishment of customs unions has sometimes been accompanied by positive environmental harmonization, a leading example being the European Community. Some FTAs have included environmental cooperation, a leading example being the North American Free Trade Agreement and its parallel side agreement. :The only trade preference program with an environmental component is the European Community's GSP programme. Since 2001, it has included "special incentive arrangement". for the protection of the environment. The current programme provides a special incentive arrangement for "sustainable development and good governance". that seeks ratification and effective implementation of listed treaties on human rights, labour rights, the environment, and good governance.

So far, this European GSP environmental arrangement has not been challenged in WTO dispute settlement. Nevertheless, when India won its challenge in 2004 against the feature of the European GSP related to drug production and trafficking, the Appellate Body held that WTO secondary law requires a GSP donor country to "respond positively" to the particularized "development, financial and trade needs of developing countries". 52 . This holding can be read as permitting the EC's preference relative to products from sustainably managed tropical forests if sustainable timber management is considered to be a development need. If sustainable timber management is not considered a development need; then the Appellate Body's holding would seem to disallow that sort of environmental conditionality in a GSP programme.

In addition to being subject to the GATT, environmental regulations (including ecolabel: ing requirements) that apply to imported products will be subject to the WTO Agreement on Technical Barriers to Trade. ${ }^{53}$. This Agreement has numerous rules; only a few will be discussed here. A technical regulation is broadly defined as a government document laying down product characteristics or their "related processes and production methods". ${ }^{4}$ One core TBT rule is that a governmental regulation "shall not be more trade-restrictive than necessary to fulfil a legitimate objective, taking account of the risks that non-fulfilment would create." ${ }^{5}$ Although no caselaw yet exists, one expert has argued that this rule requires that when a regulation is claimed to be based on science, the regulator will need to be acting on a risk assessment. ${ }^{56}$

49 Ibid. at para. 7.348.

so Ibid. at para. 7.95 .

s1 $\quad$ lbid. at paras. $7.54,7.76,7.78$.

52. European Communities-Conditions for the Granting of Tariff Preferences to Developing Countries (2004), WTO Doc. WT/DS246/AB/R at paras. 162-165 (Appellate Body Report).

53 Agreement on Technical Barriers to Trade (1994).

54 "lbid., Annex.

55 Ibid., art. 2.2.

56 Doaa Abdel Motaal, "The 'Multilateral Scientific Consensus' and the World Trade Organization" (2004) 38(5) Journal of World Trade 855 at 857-859. 
Another core TBT rule is that when a relevant international standard exists, a government's technical regulation shall use that international standard as a basis for its regulation, unless the standard would be "an ineffective or inappropriate means" for the fulfilment of a legitimate objective. ${ }^{57}$ Standards are defined broadly and include environmental product standards. A "legitimate objective" is defined to include "protection of human health or safety, animal or plant life or health, or the environment." 58 Although a textual reading of the TBT Agreement suggests that its rules on international standards apply only to standards based on consensus, the Appellate Body has held that no consensus is required. Thus, a standard formulated through voting can be enforceable by the WTO, even against governments that objected to it at the time of adoption. ${ }^{59}$

The scholarly commentary on the TBT Agreement emphasizes how the rule on the use of international standards (TBT art. 2.4) can undermine a government's effort to employ a regulation that seeks a higher level of protection than an international standard. Yet one should also recognize that the TBT rule could possibly work in the opposite direction. That is, the TBT Agreement could be interpreted to require laggard governments to move up to an international standard. On the other hand, TBT Article 12.4 states that developing countries may adopt regulations "aimed at preserving indigenous technology and production methods and processes compatible with their development needs" and that "developing country Members should not be expected to use international standards which are not appropriate to their development, financial and trade needs". ${ }^{60}$

Various rules in the TBT Agreement encourage governments to provide regulatory assistance to developing countries. Assistance is to be provided on the "preparation" of regulations and on the "methods" by which regulations can be met. ${ }^{61}$ So far, however, very little implementation of the latter occurred.

For certain health-related regulations, TBT rules are supplanted by the Agreement on the Application of Sanitary and Phytosanitary Measures. ${ }^{62}$ Any specific measure covered by the SPS Agreement is carved out of the TBT Agreement. As there is considerable literature on SPS rules and their relation to biosafety and precaution, ${ }^{63}$ the discussion below on SPS will be brief.

The SPS Agreement contains numerous disciplines on regulations (or import bans) used to protect human, animal or plant life against the classes of risks designated in the SPS Agreement. Such measures are to be based on scientific principles and may not be maintained without sufficient scientific evidence. Measures also need to be based on a risk assessment. Nevertheless, the SPS Agreement contains a clause (art. 5.7) to allow flexibility in instances where relevant scientific evidence is insufficient to perform a risk assessment. According

57 Supra note 53 , art. 2.4 .

s8 Supra note 53, art. 2.1.

59 See supra note 53, Annex 1, para. 2 (explanatory note distinguishing between international standards and other standards covered by the Agreement); European Communities-Trade Description of Sardines (2002), WTO Doc. WT/DS231/AB/R at para. 227 (Appellate Body Report).

60 Supra note 53, art. 12.4 .

61 Supra note 53, arts. 11.1, 11.3.2.

6215 April 1994, WTO Agreement, Annex 1A [SPS Agreement].

63 For example, see Laurence Boisson de Chazournes \& Urs P. Thomas, "The Biosafety Protocol: Regulatory Innovation and Emerging Trends" (2000) 4 Swiss Review of International and European Law 513; Steve Charnovitz, "The Supervision of Health and Biosafety Regulation by World Trade Rules" (2000) 13(2) Tul. Envtl. L.J. 217; Nick Covelli \& Viktor Hohots, "The Health Regulation of Biotech Foods under the WTO Agreements" (2003) 6(4) J. Int'l Econ. L. 773; Olivette Rivera-Torres, "The Biosafety Protocol and the WTO" (2003) 26 B.C. Int'l \& Comp. L. Rev. 263; Terence P. Stewart \& David S. Johanson, "A Nexus of Trade and the Environment: The Relationship Between the Cartagena Protocol on Biosafety and the SPS Agreenent of the World Trade Organization" (2003) 14 Colo. J. Int'l Envtl. L. \& Pol'y 1; Patrick J. Vallely, "Tensions between the Cartagena Protocol and the WTO: The Significance of Recent WTO Developments in an Ongoing Debate" (2004) 5 Chicago J. Int'l L. 369; Doaa Abdel Motaal, "Is the World Trade Organization Anti-Preciution?" (2005) 39(3) J. World Trade 483. 
to the Appellate Body, the Precautionary Principle "finds reflection" in that clause. ${ }^{64}$ So far, every national SPS measure challenged has been determined by WTO panels to be a violation of trade rules. Unfortunately, the WTO has no provisions for liability and redress due to damage resulting from transboundary movements of harmful organisms when the WTO itself has directed governments to permit such movement.

The SPS Agreement privileges international standards set by the Codex Alimentarius Commission, by the International Office of Epizootics, and set under the auspices of the International Plant Protection Convention. ${ }^{65}$ A government is to base its SPS measures on such standards, but may choose a higher level of protection if there is a scientific justification or if the level of protection is set in accordance with SPS rules, including a requirement to "avoid arbitrary or unjustifiable distinctions in the levels it considers to be appropriate in different situations, if such distinctions result in discrimination or a disguised restriction on international trade". ${ }^{66}$ Because the SPS Agreement relies on international standards that need not be consensus standards (e.g., Codex standards), the WTO has the potential to become the enforcer of rules that some WTO members have previously rejected.

Note that it may be possible under SPS Article 3.1 to bring a WTO complaint against an SPS measure that results in a lower level of protection than would be achieved by measures based on relevant international standards so long as the measure affects international trade. Such a cause of action was probably not intended by the drafters of SPS, however, and one can point to statements by the Appellate Body which would seem to foreclose such a challenge. In the Australia-Salmon case, the Appellate Body stated the "determination of the appropriate level of protection ... is a prerogative of the Member concerned and not of a panel or the Appellate Body". ${ }^{67}$ In the Hormones case, the Appellate Body took note of an SPS preambular provision suggesting international harmonization be furthered "without requiring Members to change their appropriate level of protection of human, animal or plant life or health". ${ }^{68}$ On the other hand, immediately after making that point, the Appellate Body declared that "The right of a Member to define its appropriate level of protection is not, however, an absolute or unqualified right". ${ }^{69}$ Furthermore, the Appellate Body stated:

In generalized terms, the object and purpose of Article 3 is to promote the harmonization of the SPS measures of Members on as wide a basis as possible, while recognizing and safeguarding, at the same time, the right and duty of Members to protect the life and health of their people. The ultimate goal of the harmonization of SPS measures is to prevent the use of such measures for arbitrary or unjustifiable discrimination between Members or as a disguised restriction on international trade, without preventing Members from adopting or enforcing measures which are both "necessary to protect" human life or health and "based on scientific principles", and without requiring them to change their appropriate level of protection. The requirements of a risk assessment under Article 5.1, as well as of "sufficient scientific evidence" under

64 EC Measures Concerning Meat and Meat Products (Hormones) (1998), WTO Doc, "WT/DS26,48/AB/R at para. 124 (Appellate Body Report) [Hormones]. In a more recent case, a panel noted that the Cartagena Biosafety Protocol has "confirmed the key function of the precautionary principle" in international law. Japan-Measures Affecting the Importation of Apples (2003), WTO Doc.:WT/DS245/R at para. 5.34, note 161 (Panel Report).

653 April 1952, as amended by th FAO Conference at its Twentieth Session (November 1979) and at its Twentyninth Session (November 1997), online: FAO. <http:/www.fao.org/Legal/TREATIES/004t-e.htm>.

66 SPS Agreement, supra note 62, arts. 3.1, 5.5.

67 Australia-Measures Affecting Importation of Salmon (1998), WTO Doc. WT/DS18/AB/R at para. 199 (Appellate Body Report).

68 Hormones, supra note 64 at para. 172.

69 Hormones, supra note 64 at para, 173. 
Article 2.2, are essential for the maintenance of the delicate and carefully negotiated balance in the SPS Agreement between the shared, but sometimes competing, interests of promoting international trade and of protecting the life and health of human beings. ${ }^{70}$

Thus, one can read this paragraph as saying that the Appellate Body sees a "duty" of Members to protect the life and health of their people. The Appellate Body also sees a competing interest in the SPS Agreement between the two objectives of trade promotion and protecting human life and health. Up until now, most analysts have focused on the paradigm case of the triumph of trade over health. Yet one wonders whether a government that lets export objectives trump its health duties could run afoul of the required SPS balance if that government chooses not to base an SPS measure on an existing international standard, but rather chooses to under-regulate.

Policy issues regarding SPS are decided by the WTO's SPS Committee which acts by consensus. Although the Secretariat of the Convention on Biological Diversity has requested observer status at the WTO's SPS Committee, such status has not yet been granted.

The next policy instrument to be considered is the government subsidy. The Agreement on Subsidies and Countervailing Measures ${ }^{71}$ prohibits subsidies that have specificity and that cause "adverse effects to the interests" of WTO member countries. ${ }^{72}$ Originally, the SCM Agreement exempted certain environmental subsidies from this prohibition, but that derogation expired at the end of 1999, and the WTO member governments did not renew it (arts. 8.2(c), 31). The exempted subsidies were for assistance to promote adaptation of existing facilities to new environmental requirements. According to the WTO Secretariat, the defunct SCM provision was "intended to allow Members to capture positive environmental externalities when they arose."73 Its expiration leaves subsidies to correct market failure subject to being challenged as WTO violations. So far, none have been.

Agricultural subsidies are also governed by complex rules in the Agreement on Agriculture that commit countries to limit and reduce subsidies. For many kinds of subsidies that have no trade-distorting effects (the so-called "green box"), no reductions in support are required. Some subsidies for environmental programmes are included in the Green Box. The Preamble of the Agreement on Agriculture suggests that its commitments have been made with regard to "the need to protect the environment."74 Perhaps the major implication of the Agriculture Agreement for the environment is that many agricultural subsidies lead to perverse incentives for production that entail environmental degradation. The ongoing agricultural trade negotiations may eventually curtail such subsidies, but so far, negotiators have not focused on the environmental harms from subsidies.

Finally, some provisions in the WTO mandate trade controls. The now-expired Agreement on Textiles and Clothing, which liberalized trade, also called on WTO members to take action against "circumvention", defined as "transhipment, re-routing [and] false declaration concerning country or place of origin, or as "falsification of official documents". 75 Such circumvention practices are also of concern to many environmental treaty systems, but the WTO does not utilize trade controls to achieve environmental goals.

70 Hormones, supra note 64 at para. 177.

71 April 1994, online WTO <http://www.wto.org/english/docs_e/legal_e/24-scm_01_e.htm> [SCM Agreement].

72 Ibid., arts. 2, 5 .

7.3 WTO, "Agreement on Subsidies and Countervailing Measures", online: WTO < http://www.wto.org/english/ tratop_c/envir_c/cnvir_backgrnd_e/c7s8_e.htmi>.

7415 April 1994, WTO Agreement, supra note 21, Annex 1A.

7515 April 1994, WTO Agrcement, supra note 21, Annex 1A, art. 5.1 (expired). 


\section{B. Trade in Services}

The second fount of WTO law is trade in services. The General Agreement on Trade in Services ${ }^{76}$ can have significant environmental consequences. A key environmental plus is that the GATS may help enable governments to be more open to the importation of environmental services. The GATS also facilitates the movement of natural persons both to consume services (e.g., students who attend a foreign university to study environmental science) and to deliver services (e.g., trained environmental technicians who provide assistance in another country). Counterbalancing these positive repercussions from the GATS are the new disciplines that governments agree to accept: Environmental measures in the form of regulations, taxes, or import bans will be subject to numerous GATS rules. For the most part, the GATS rules apply only to sectors where government makes commitments.

In contrast to the GATT which has two broad general exceptions applicable to the environment, the GATS has only one environmental exception:- That exception applies to measures necessary to protect human, animal or plant life or health. Thus, the GATT's environmental exception for conservation was purposefully omitted from the GATS. ${ }^{77}$

Although no environment disputes have arisen in the GATS, the absence of a conservation exception may make it hard to defend an environmental regulation subject to a dispute in the WTO. Challenging an environmental regulation was made easier by a WTO decision in U.S.-Gambling ${ }^{78}$ which held that criminal laws prohibiting noxious services can be considered a zero quota violating GATS Article XVI (Market Access). ${ }^{79}$ This surprising holding resulted when three longtime U.S. laws banning remote gambling were found to violate Article XVI despite the fact that they were applicable de jure to domestic as well as cross-border gambling services.'

The governments that negotiated the GATS missed an opportunity to accord deference to the environment regime in the same way that deference is accorded to other regimes. For example, the GATS provides full deference to the rights and obligations of members of the International Monetary Fund and to multilateral agreements regarding double taxation. ${ }^{80}$ No analogous provisions exist to respect multilateral regimes on environment or public health.

The GATS does not define "services", an omission that has led observers to question whether certain environmental rights are to be considered services under the Agreement. For example, does a GATS-covered service include a right to pollute (e.g., a carbon emission permit), a right not to be polluted, or a right to exploit a natural resource (e.g., a fishery quota)? In my view, such government-created rights are not covered services, but no official interpretation of WTO caselaw yet exists.

\section{Intéllectual Property}

The third fount of substantive WTO law is the Agreement on Trade-Related Aspects of Intellectual Property Rights. ${ }^{81}$ This Agreement mandates that WTO member governments provide a minimum level of intellectual property protection to nationals of other

7615 April 1994, WTO Agreement, supra note 21, Annex 1B [GATS].

77 David Waskow, "Environmental Services Liberalization: A Win-Win or Something Else Entirely?” (2003) 37(3) Int'l Law. 777 at 793-795.

78 United States-Measures Affecting the Cross-Border Supply of Gambling and Betting Services (2005), WTO Doc. WT/DS285/AB/R at paras. 237-238 (Appellate Body Report). A government could stay out of violation if it lists the national law in its negotiating schedule. ${ }^{f}$ This can shelter pre-existing environmental laws, but would be useless for new environmental laws.

79 Supra note 76 , art. XVI.

80) Supra note 76 , arts. XI:2, XIV(e)

81 15 April 1994, online: WTO < http://www.wto.org/english/docs_e/legal_e/27-trips_01_e.htm > [TRIPS]. 
WTO member countries. On some matters, TRIPS mandates that governments follow certain requirements of pre-existing intellectual property treaties. On other matters, TRIPS prescribes its own minimum requirements. ${ }^{82}$ The TRIPS Agreement (art. 8.1) gratuitously states that governments "may ... adopt measures necessary to protect public health and nutrition ... provided that such measures are consistent with the provisions of this Agreement." 83

Patenting is the field of intellectual property most likely to have a significant effect on environmental and health quality. Under TRIPS, governments are required to issue patents in all fields of technology, but "may exclude from patentability inventions, the prevention within their territory of the commercial exploitation of which is necessary to protect ordre public or morality, including to protect human, animal or plant life or health or to avoid serious prejudice to the environment, provided that such exclusion is not made merely because the exploitation is prohibited by their law". 84

The probable effects of TRIPS on the environment will likely be mixed. A positive effect on the availability of technology is to be expected if patenting leads to more innovation. On the other hand, a negative effect may ensue, especially in lower-income countries, if there are higher costs of obtaining products of foreign innovation. ${ }^{85}$ The technology that has been the most contentious in the WTO until now has been pharmaceuticals. ${ }^{86}$

The TRIPS Agreement calls on WTO members to cooperate with each other in eliminating international trade in goods infringing intellectual property rights (art. 69). The Council on TRIPS cooperates with other international organizations, but so far the Council for TRIPS has failed to act on some requests for observer status by major environmental agencies. For example, the Council has not given observer status to the U.N. Environment Programme (UNEP) or the Secretariat for the Convention on Biological Diversity. ${ }^{87}$

The TRIPS Agreement has an important pro-development principle that so far has seen little activity or oversight. TRIPS Article 66.2 obliges developed countries to provide incentives to enterprises and institutions in their territories for the purpose of promoting and encouraging technology transfer to least-developed countries in order to enable them "to create a sound and viable technological base". ${ }^{88}$ A possible synergy exists between this provision and the promotion of sustainable development. On the other hand, a possibility of legal conflict exists between this provision and the prohibitions in the SCM Agreement against actionable subsidies and de facto export subsidies. ${ }^{89}$

\section{The WTO's Institutional Provisions}

Although the environment is not mentioned in the Marrakesh Agreement Establishing the WTO $^{90}$ beyond the text of its Preamble, and is not mentioned in the WTO Dispute

82 See UNCTAD-ICTSD, Resource Book on TRIPS and Development (Cambridge: Cambridge University Press, 2005).

83 Supra note 81.

84 Supra note 81, art. 27.2. Exclusion is also possible for animals other than micro-organisms, as provided for in the complex rule laid out in TRIPS Article 27.3. See also the Convention on Biological Diversity, supra. note 1 , art. 16.5 (regarding intellectual property rights).

85 Alejandro Nadal, "Redesigning the Trading System for Sustainable Development" (2005) 9(5) Bridges 21 at 22.

86 Frederick M. Abbott, "The WTO Medicines Decision: World Pharmaceutical Trade and the Protection of Public Health", (2005) 99(2) Am. J. Int'l L. 317.

87 Laurence R. Helfer, "Mediating Interactions in an Expanding International Intellectual Property Regime" (2004) 36(1) Case W. Res. J. Int'l L. 123 at 131.

88 Compare to Article 22 of the Cartagena Protocol on capacity building.

89 See supra note 71 , arts. $3,5$.

90 April 15, 1994, online: WTO <.. http://www.wto.org/english/docs_e/legal_e/04-wto_e.htm>. 
Settlement Understanding, there are four ways in which the WTO's institutional provisions have implications for the environment.

One is the operation of the WTO Committee on Trade and Environment (CTE). Although the Committee has not reached any significant decisions, it may be having some positive impact, in serving as a continuing forum on international trade and the environment. The existence of such a forum is significant for the environment regime because there is insufficient ongoing attention in global institutions for considering the tensions between economic and environmental goals. To be sure, some other international institutions do exist, such as UNEP, the U.N. Commission on Sustainable Development, and the Roundtable on Sustainable Development sponsored by the Organization for Economic Co-operation and Development (OECD). But none of these entities has advanced the debate on "trade and environment" in recent years. One interesting feature of the CTE is that it is the only intergovernmental forum in which Taiwan is allowed to participate, even though Taiwan's economy is one of the world's 20 largest.

A second institutional provision is accession to the WTO. The countries that were not original members of the WTO must join through an accession negotiation. A country seeking to join may do so only "on terms to be agreed between it and the WTO". 91 This provision makes clear that it is the WTO itself that has the authority to propose the entry terms. Because almost every country today wants to join the WTO (even North Korea has now sought observer status), the WTO has considerable leverage in those accession negotiations. Unfortunately, lengthy delays have become the norm. ${ }^{92}$ Furthermore, there is little public debate as to how the WTO's bargaining surplus should be used. The lack of public debate may stem from the secrecy of the WTO accession process.

In China's accession, the biggest negotiation so far, the WTO used its leverage to insist on both WTO-minus and WTO-plus provisions. Incumbent WTO-minus provisions occur when the WTO reduces the normal rule-based obligations owed to the applicant country; in other words, incumbent members are allowed to discriminate against the applicant country. For example, the WTO did this to China on textiles and apparel trade in order to gratify protectionist impulses of its members toward China. ${ }^{93}$ Applicant WTO-plus provisions occur when the WTO demands that the applicant government agree to rules beyond those normally required of WTO members. For example, the WTO did this to China in asking it to commit not to impose performance requirements of any kind on inward foreign investment. ${ }^{94}$

Because of its hegemonic position in the world economy, the WTO can use its bargaining leverage for any issue it wants. Ideally, the WTO should use that leverage for a public benefit. In particular, the WTO could promote global general interests rather than special interests. Telling general from special may not always be easy, but giving balm to European and U.S. textile manufacturers hardly seems a general interest. Apparently, the WTO did not even consider the possibility of using its leverage to convince China to upgrade its industrial practices that cause harmful environmental effects on other countries. ${ }^{95}$ These gaps show the possibility for greener accession negotiations.

A third WTO institutional provision are the compliance measures available in the dispute settlement process if a WTO member loses a case and refuses to comply. Should that occur, the winning plaintiff may vindicate its victory by acting to suspend concessions or other

91 Ibid., art. XII:1.

92 Gregory L. White \& James Hookway "WTO Candidates Chafe at Slow Pace of Accession" Wall Street Journal (14 December 2005) A17.

93 "Textiles Stitch-Up: Whatever the EU and China Say, Their Deal Mocks Free Trade", Editorial, Financial Times (14 June 2005) 18.

94 Julia Ya Qin, “'WTO-Plus' Obligations and Their Implications for the World Trade Organization Legal System" (2003) 37(3) J. World Trade 484 at 503.

95 "China's Mercury Pollution Affects Entire Globe, Scientists Say" Greenvire (17 December 2004). 
WTO obligations ${ }^{96}$ (SCOO). For example, in the Hormones case, ${ }^{97}$ because the European Community has not complied, the United States and Canada are imposing 100 percent tariffs against a range of goods. Yet under current WTO practice, no review occurs of what products a government chooses to target. Perhaps a review should be undertaken of the projected environmental impact of the WTO-authorized trade sanctions.

A fourth institutional provision is that the WTO General Council is tasked with making appropriate arrangements for effective cooperation with other international organizations that have responsibilities related to those of the WTO. Pursuant to this authority, the WTO has signed cooperation agreements with the World Bank, the International Monetary Fund, the World Intellectual Property Organization, and the International Office of Epizooties, and has signed a Memorandum of Understanding with the U.N. Conference on Trade and Development. ${ }^{98}$ No cooperation agreements have been signed with major institutions of the environment regime. ${ }^{99}$ Nevertheless, the Secretariat of the Convention on Biological Diversity has been permitted to attend recent WTO Ministerial conferences.

That completes the discussion of the most significant environmental features of the WTO treaty and the emerging caselaw. The other major way in which the WTO interacts with the environment is that some environmental issues are on the negotiating agenda for the Doha Round.

\section{The EnVIRonment IN WTO Negotiations}

In the Doha Ministerial Declaration, governments stated:

We strongly reaffirm our commitment to the objective of sustainable development, as stated in the Preamble to the Marrakesh Agreement. We are convinced that the aims of upholding and safeguarding an open and non-discriminatory multilateral trading system, and acting for the protection of the environment and the promotion of sustainable development can and must be mutually supportive. ${ }^{100}$

Although previous multilateral trade rounds gave marginal consideration to the environment, the Doha Round marks the first time in which the environment has explicitly been included on the negotiating agenda. To be sure, the environment is only a small component of the Round. Nevertheless, these issues loom important.

\section{A. Fishing}

The Doha Agenda commits governments to "clarify and improve WTO disciplines on fisheries subsidies, taking into account the importance of this sector to developing countries". ${ }^{101}$ Although one could conceptualize a negotiation on fisheries subsidies as merely a commercial issue, the Doha Declaration cross-lists the negotiations under the category of Trade and Environment. That makes sense because there are significant environmental benefits of removing subsidy-driven trade distortions in the fisheries sector. ${ }^{102}$ Indeed, the recent 2005

96 SCOO is the acronym for suspending concessions or other obligations. Many commentators refer to that remedy as "retaliation," but that term does not appear in the WTO treaty.

97 Supra note 64.

98 See, e.g., Online: UNCTAD <http://www.unctad.org/sections/press/docs/mou.pdf >

99 In 1995, the WTO Director-General exchanged letters with the Secretary-General of the United Nations regarding cooperation, but there is no formal inter-organizational agreenent with UNEP or any other international environmental agency. See WTO, Press Release, WTO Press 154, "Elements of Cooperation between the WTO and UNEP" (29 November 1999).

100 Doha Ministerial Declaration, WTO Doc. WT/MIN(01)DEC/1 at para. 6.

101 Ibid. at para. 28.

102 See World Trade Organization Secretariat, Environmental Benefits of Removing Trade Restrictions and Distortions: The Fisheries Sector, WTO Doc. WT/CTE/W/L67. 
Annual WTO Report characterizes the negotiations as being "aimed at restricting environmentally harmful fishing subsidies." 103 For some analysts, the fishery negotiations go too far in flirting with environmental conditionality in a trade agreement. ${ }^{104}$

Although at the advent of the negotiations, some governments were taking the position that the SCM Agreement should not have sector-specific provisions, this objection has seemingly diminished in recent years as the negotiators discuss the details of supervision proposals.

The concern about government subsidies for fisheries is that such subsidization leads to overcapacity of fishing and overfishing, and therefore to a depletion of world fish stocks. World fish stocks are currently threatened by overfishing, and despite a skein of international agreements governing fishing, there is still a great deal of illegal, unregulated, and unreported fishing. ${ }^{105}$ Unless management improves, fish stocks could be severely depleted. The degree of fisheries subsidization is estimated to be about 20-25 percent of total fisheries revenue.

At the Hong Kong Ministerial in December 2005, the WTO Declaration declared that there was broad agreement that the Negotiating Group on Rules "should strengthen disciplines on subsidies in the fisheries sector, including through the prohibition of certain forms of fisheries subsidies that contribute to overcapacity and over-fishing ..."106 The Declaration called on participants to undertake detailed work to "establish the nature and extent of those disciplines, including transparency and enforceability."107 In addition, the Declaration calls for appropriate and effective S\&D treatment for developing and least-developed WTO Members.

Many proposals have been offered in the WTO including proposals for a ban on fisheries subsidies that would be conditioned on certain fishery management indicators. ${ }^{108}$ The conditioning of subsidy rules on management indicators would be an interesting development because it would provide a linkage between the WTO rules and the ongoing work of other international organizations, such as the regional fisheries management organizations. ${ }^{109}$ To the extent that fishery management programmes allocate marketable rights, that could constiture a subsidy under the SCM agreement.

\section{B. Environmental Goods and Services}

A second important environment-related issue on the Doha Agenda is the negotiation for the reduction or elimination of tariff and non-tariff barriers to environmental goods and services. ${ }^{110}$ Although such negotiations are a trade liberalization objective, they are also an environmental objective, and the environmental benefit may be just as significant as the trade benefit. After all, current barriers to trade in, for example, pollution control technology, could not possibly be beneficial for the environment. Recently, an NGO-sponsored analysis

103 World Trade Organization, Annual Report (Geneva: WTO, 2005) at 153.

104 Roman Grynberg and Natallie Rochester, "The Emerging Architecture of a World Trade Organization Fisheries Subsidies Agreement and the Interests of Developing Coastal States" (2005) 39(3) J. World Trade 503.

105 U.N. Food and Agriculture Organization, "Stopping Illegal, Unreported and Unregulated (IUU) Fishing," online: $\mathrm{F} A \mathrm{O}<\mathrm{http} / / \mathrm{www}$. fao.org/docrep/005/y 3554e/y $3554 \mathrm{e} 01 . \mathrm{htm}>$.

106 Hong Kong Ministerial Declaration, WTO Doc. WT/MIN(05)/W/3/Rev. 2, Annex D, Part I at para. 9.

107 Ibid.

108 See, for example, Proposal from the United States, Fisheries Subsidies: Proposed New Disciplines, WTO Doc. TN/RL/GEN/145.

109 Note that under the current WTO Agreement, new developments extrinsic to the WTO can lead to new obligations within the WTOO. For example, TBT art. 2.4 requires governments to use international standards as a basis for technical regulations.

110 Gary P. Sampson, "The World Trade Organization and Global Environmental Governance" in W. Bradnee Chambers \& Jessica F. Green eds. Reforming International Environmental Governance (Tokyo: U.N. University Press, 2005) 93 at 141. 
suggested that negotiators focus on environmentally-preferable products based on a life-cycle analysis. ${ }^{111}$

As in any WTO negotiation, definitional issues regarding environmental goods have been at the center of the talks. For example, what are environmental goods? At present, WTO tariff rules and the harmonized tariff nomenclature do not specifically address the end use of an item or its environmental footprint. By early 2007, there were nine different lists of environmental goods in play. Alternative approaches were suggested by India and Argentina-namely, a project-oriented approach suggested by India and an integrated approach suggested by Argentina to reconcile the two approaches. A challenging conceptual issue has been how to handle goods that are not used for pollution control or remediation, but rather are more energy efficient or less environmentally harmful than alternative goods. This category is called environmentally preferable products and some lists of those products include ethanol. In commenting on these negotiations, the WTO Secretariat has noted that liberalizing trade in environmental goods can encourage the use of new environmental technologies and make it easier for countries to obtain high quality goods.

The GATS services sectoral classification list covers "Environmental Services" under Section 6 and the subsector categories are: sewage services (9401), refuse disposal services (9402), sanitation and similar services (9403), and other services. The Central Protection Classification (CPC) has additional relevant categories such as: cleaning of exhaust gases (9404), noise abatement services (9405), nature and landscape protection services (9406), and other environmental services (9409). Of course, because of the pervasiveness of environmental considerations, any taxonomy is likely to be incomplete, just as the CPC is. Thus, one can see that many other CPC categories can include environmental services-for example, natural water (180), engineering (8672), urban planning and landscape architectural services (8674), R\&D on natural sciences (851), technical testing and analysis (8676), higher education (923), services incidental to energy distribution (887), travel agencies and tour operators (7471), transportation of fuels (7131), etc. In the Uruguay Round and subsequent accession negotiations, about 50 WTO members made commitments in the environmental services classified in the 9400 s, but the Secretariat has assessed these as "rather limited." 112 Most of the existing commitments involve mode 3 (commercial presence).

The negotiators present an opportunity to formulate many new environmental services commitments. For example, governments can liberalize entrance visas for environmental technologists (under GATS Article XVI mode 4). Governments can also give bindings for exit visas for students who want to study environmental sciences in other countries (under GATS Article XVI mode 2.) In addition, governments can use GATS Article XVIII to make commitments on the export of services through modes 1 through 4 . For example, a government could agree not to apply unnecessary export controls to environmental technology needed in other countries.

One important service sector that has been highlighted is ecotourism where trade, investment, and ecological objectives can be mutually supportive. Green Globe, an NGO, has worked with major stakeholders in developing eco-tourism labels that can help to bring transparency and accountability to this sector. Ecotourism consumption is mode 2. Although most regulation of ecotourism is by the host country, the WTO GATS commitments normally apply only to the home country of the service consumer.

So far, three themes reportedly have emerged in the environmental services negotiations. First, governments see a need for better classification of services. Second, governments

111 Robert Howse \& Petrus B. van Bork "Liberalising Environmental Goods in the Doha Round" (2005) 9(8) Bridges 12.

112 WTO Secretariat, Environmental Aspects of the Negotiations, Note by the Secretariat, WT/CTE/W/243, 27 Novenuber 2006, para. 58. 
consider mode 3 the most important followed by mode 4 . Third, some regulatory issues have been raised, particularly the recognition of professional qualifications. Government officials engaged in GATS negotiations can consult the Negotiating Checklist on environmental services prepared in the OECD. ${ }^{113}$ More detailed discussion of these negotiations is hindered by the fact that the WTO Secretariat has classified some of the documentation for this negotiation in its confidential JOB series, and therefore that documentation is not publicly available.

\section{Win-Win-Win Scenarios}

A third environment component is "attention to situations in which the elimination or reduction of trade restrictions and distortions would benefit trade, the environment and development". ${ }^{114}$ Environmentalist groups welcomed this commitment who saw in the possibility of WTO scrutiny of particular sectors. Some progressive business groups were also pleased. In an "Environment Backgrounder", the WTO Secretariat pointed out several sectors where there could be "environment benefits of removing trade distortions". 115 The current state-of-play is that WTO members are discussing whether to negotiate.

Although some sectoral policy was written into the WTO treaty-most notably in agriculture, textiles and clothing, and telecom-not much attention has been given to re-organizing the WTO's environment work into sectors. Several sectors could benefit from more integrated attention including aquaculture and fisheries, chemicals, energy goods and services, environmental goods and services, forestry, mining, tourism, and transport. For each sector, governments could consider how to improve environmental quality using the WTO rules on subsidy reduction, regulations and standards on goods, regulations and standards on services, and technical assistance for developing countries. In that connection, the WTO could develop a list of recognized standard-setting bodies engaged in the development of environmental and sustainability standards. ${ }^{116}$

\section{Multilateral Environmental Agreements (MEAs)}

WTO members are negotiating on the relationship between WTO rules and specific trade obligations set out in multilateral environmental agreements (MEAs). This issue is important because although MEAs have been using trade controls for over a century, there is a body of opinion inside the WTO that such controls are a violation of WTO rules and should no longer be permitted as environmental instruments. Many WTO member governments probably agree with Alan Oxley, the former GATT Council chairman, who has criticized leading MEAs for using "trade coercive measures" that disregard "national sovereignty". ${ }^{117}$

That opposition to trade measures in MEAs seems to have chilled the inclusion of trade controls in new MEAs. Other than the Stockholm Convention on Persistent Organic Pollutants (2001), ${ }^{118}$ no MEA negotiated during the past seven years contains specific trade obligations.

\footnotetext{
113 OECD, OECD Trade Policy, Working Paper No. 11, Doc No. TD/TC/WTP(2004)/8/ (2005) at para. 74.

114 Supra note 100 at para. 32(i).

115 WTO, supra note 38 at 22.

116 Bradnee Chambers, "WTO and Sustainable Development" in Tatsuro Kunugi cd. Taking Leadership in Global Governance (Osawa: International Christian University, 2004) 79 at 81.

117 Alan Oxley, "The Relationship Between MEAs and WTO Rules" in UNCTAD, Trade and Environmen Review 2003 (Geneva: UNCTAD, 2004) at 93-96.

1189 March 2001, 40 I.I.M. 532.
} 
The U.N. biodiversity regimes includes some obligations that may entail trade measures. The Convention on Biological Diversity (art. $8(\mathrm{~h}))^{119}$ directs parties to "[p]revent the introduction of, control or eradicate those alien species which threaten ecosystems, habitats or species ...". ${ }^{120}$ The Cartagena Protocol (art. 16.3) directs parties to take appropriate measures "to prevent unintentional transboundary movements of living modified organisms...". 121

Although there was some hope by environmentalists that the WTO's threat to MEAs could be eliminated in the new trade round, the Doha Agenda is highly circumscribed and is unlikely to lead to any fruitful outcome. Specifically, the governments have precluded any negotiation on trade measures applying to non-parties to the MEA and any result that would "add to or diminish the rights and obligations of Members under existing WTO agreements ...". ${ }^{122}$ Seemingly then, the negotiators cannot propose changes to WTO rules, even if needed.

When MEAs apply specific trade obligations to non-parties, they can do so in two ways. One is to apply the same measure to a non-party as the MEA applies to a party (e.g., CITES). The other is to apply a discriminatory measure against a non-party (e.g., the Montreal Protocol on the Ozone Layer). ${ }^{123}$ Both approaches are controversial within the WTO, but the second is more controversial because it involves discrimination. Yet this stance seems a bit hypocritical because the WTO itself does not insist upon non-discrimination against its own non-parties. WTO Member governments are given total flexibility to discriminate against non-Members. Even worse, when the WTO negotiates an accession agreement with a non-Member, the WTO may insist that the applicant country accept discrimination against it as a condition for joining (e.g., the China Accession Protocol). ${ }^{124}$

Recently, a team of environmental analysts offered a good suggestion for "shifting the hapless debate within the CTE [WTO Committee on Trade and Environment] around MEAs toward a useful purpose." 125 They recommend that the WTO look at each MEA and consider what particular trade liberalization, in goods and services, would help to meet the objective of that MEA.

\section{E. TRIPS and Biodiversity}

Although not listed as an environmental negotiating issue, the relationship between the TRIPS Agreement and the Convention on Biological Diversity is included on the Doha Agenda as an action item for the WTO Council on TRIPS. Specifically mentioned are the rules for patentability of plants and animals other than microorganisms and for patentability of traditional knowledge and folklore. So far, governments have not reached a decision regarding whether to commence negotiations.

The TRIPS Agreement contains no patent discipline to prevent biopiracy. This gap has been noted in ongoing negotiations, and several countries have proposed amendments to TRIPS that would allow governments to require patent applications to disclose the source and country of origin of any biological resources or traditional knowledge used in inventions. ${ }^{126}$

119 Cartagena, supra note 1.

120 Peter T. Jenkins, "International Law Related to Precautionary Approaches to National Regulation of Plant Imports" (2005) 39(5) J. World Trade 895 at 900-901.

121 Cartagena, supra note 1.

122 Supra note 100 at para. 32.

12316 September 1987, 26 I.L.M. 1541.

124 Online: WTO < http://www.wto.org/english/thewto_e/acc_e/protocols_acc_menbership_e.htm>.

125 Chantal Line Carpentier, Kevin P. Galligher \& Scott Vaughan "Environmental Goods and Services in the World Trade Organization", (2005) 14(2) Journal of Environment \& Devclopment 225 at 249.

126 For example, see the excellent paper by the Government of Peru, IP/C/W/447, 8 June 2005. 


\section{F. Environmental Reviews}

The Doha Declaration tasks the WTO Committee on Trade and Development and the Committee on Trade and Environment to each act, within their respective mandates, "as a forum to identify and debate developmental and environmental aspects of negotiations ...". ${ }^{127}$ Immediately after Doha, hopes were high in the environment community that this mandate would lead to a careful process of environmental impact assessment of proposed negotiating outcomes. Aaron Cosbey, of the International Institute for Sustainable Development, proposed several options for how the two WTO Committees could carry out such efforts. ${ }^{128}$ Unfortunately, neither Committee initiated a robust assessment process. ${ }^{129}$ Doing so now would not be too late.

In 2002, the Johannesburg Plan of Implementation called for "urgent action" to "support the successful completion of the work programme contained in the Doha Ministerial Declaration..." 130 The U.N. Conference was correct to see the importance of successful WTO negotiations for the goal of sustainable development. Unfortunately, due to various machinations in national capitals, WTO negotiators have missed all of the Doha Round target dates, and the talks continue to drag on as of mid-2007.

\section{ThE WTO, BIOSAFETY AND ENVIRONMENTAL GOVERnANCE}

The WTO does not have any provisions calling on governments to protect biological diversity and promote biosafety. The closest one gets on biosafety is the SPS provision regarding adaptation to regional conditions which obligates WTO Members to

... recognize the concepts of pest- or disease-free areas and areas of low pest or disease prevalence. Determination of such areas shall be based on factors such as geography, ecosystems, epidemiological surveillance, and the effectiveness of sanitary or phytosanitary controls. ${ }^{131}$

Yet one should note that in its Shrimp decision, the Appellate Body quoted the provision (art. 5) of the Convention on Biological Diversity that calls on parties to "cooperate with other contracting parties directly or, where appropriate, through competent international organizations, in respect of areas beyond national jurisdiction and on matters of mutual interest, for the conservation and sustainable use of biological diversity". ${ }^{1.32}$ In doing so, the Appellate Body demonstrated its view that the Convention is relevant to the interpretation of the WTO treaty.

Even without a specific legal rule to promote biosafety, the WTO can be enormously important to future efforts to achieve that goal. The WTO may affect biosafety in two main ways-through facilitating trade and through supervising certain governmental actions that affect trade. In EC-Approval aind Marketing of Biotech Products, the panel found that the EC's biotech regulation violated the SPS Agreement. ${ }^{133}$ In the course of its decision, the

127 Supra note 100 at para. 51.

${ }^{128}$ Aaron Cosbey, "Taking the Doha Language Seriously: The WTO As if Sustainable Development Really Mattered" (Paper presented to the Royal Institute of International Affairs conference: Sustainable Development in the New Trade Round: Trade, Investment and Environment after Doha, May 2002) online: IISD $<$ http://www.iisd.org/pdf/2002/trade_riia_paper_may2002.pdf >.

129 International Centre for Trade and Sustainable Development and International Institute for Sustainable Development (ICTSD-IISD), Doba Round Briefing Series (No. 9/13) (November 2005) at 37.

130 Johannesburg Plan of Implementation (2002), online: UN <http://www.un.org/csa/sustdev/documents/docs.htm> at para. 47.

131 Supra note 62 , art. 6.2 .

132 Supra note 23 at para. 168.

133 European Communities-Measures Affecting the Approval and Markcting of Biotech I'roducts (2006), WTO Doc. WT/DS291/R (Panel Report). 
panel held that it was not required to take into account either the Convention on Biological Diversity or its Biosafety Protocol because both were not applicable to at least one of the parties, and therefore not applicable in the relations between all WTO members. ${ }^{134}$

The Cartagena Protocol on Biosafety does not seem to contain any mandates that violate the WTO. ${ }^{135}$ This conclusion would seem preordained by the care in which governments negotiated the Protocol in the late 1990s and 2000 to assure that it would be compatible with the WTO. Nevertheless, it would be possible for governments, when implementing the Protocol, to take actions that are WTO violations. ${ }^{136}$ Similarly, it would be possible for governments, when implementing the WTO Agreement, to take actions that violate the Biosafety Protocol.

Yet the Protocol, unlike the WTO, contains general provisions specifying deference to other obligations of international law. ${ }^{137}$ Most importantly, Article 2(4) states that:

Nothing in this Protocol shall be interpreted as restricting the right of a Party to take action that is more protective of the conservation and sustainable use of biological diversity than that called for in this Protocol, provided that such action is consistent with the objective and the provisions of this Protocol and is in accordance with that Party's other obligations under international law. ${ }^{138}$

Parsing this language, it means that if a particular action is not in accordance with a party's other obligations under international law-for example, WTO obligations-then such action is not within the set of actions that a party can take (that is, being within its "right" to take) to pursue goals that are more protective of biodiversity than called for in the Protocol. In other words, national policy space to pursue pro-biodiversity goals (beyond what is specified by the Protocol) seems to be limited whenever such goals would violate the WTO. Another deference provision in the Protocol is Article $18(1)^{139}$ which conveys obligations regarding handling, packaging, and transportation in transboundary movement, but subject to a requirement that parties take into consideration relevant international rules and standards. A third deference provision is Article $26(1)^{140}$ which clarifies that parties may take into account certain "socio-economic considerations" when consistent with their international obligations.

Although the WTO Agreement and the Cartagena Protocol have equivalent status in international law, there is sometimes a tendency among some governments to view the WTO as higher law because its obligations are enforceable through trade sanctions, while the obligations in environmental treaties are not enforceable in that manner. That pragmatic view is not easy to refute even though the equal hierarchial legal relationship between the WTO and MEAs is clear. Governments that are a member of the WTO and of an MEA are obligated to follow both sets of rules.

134 lbid. at paras. 7.74-7.75.

135 Barbara Eggers \& Ruth Mackenzie "The Cartagena Protocol on Biosafety", (2000) 3(3) Journal of Intermational Economic Law 525 at 539; Viet Koester, "The Cartagena Protocol on Biosafety: A New Hot Spot in the Trade-Environment Conflict?" in Ricardo Meléndez-Ortiz \& Vincente Sánchez, Trading in Genes. Development Perspectives on Biotechnology, Trade and Sustainability (London: Earthscan, 2005) 171 at 188. One prominent analyst disagrees. Gary Sampson has written: "Whether there are WTO-inconsistent measures in the Biosafety Protocol seems to be answered in the affirmative, at least as far as the treatment of precaution in the SPS Agreement is concerned" (Gary P. Sampson, The WTO and Stistainable Development (Tokyo: U.N. University Press, 2005) at 153).

136 The Cartagena Protocol provisions in greatest tension with the WTO may be Articles 10.6 and 11.8 regarding national decisions in the absence of scientific certainty (Sabrina Safrin, "Treaties in Collision? The Biosafety Protocol and the World Trade Organization Agreements" (2002) 96(3) Am. J. Int'l L. 606 at 612, 624-625).

137 Commentators somctimes note that the last paragraph of the Preamble to the Cartagena Protocol states that the penultimate paragraph is not intended to subordinate the Protocol to other international agreements.

138 Cartagena, supra note 1.

139 Cartagena, supra note 1.

140 Cartagena, supra note 1. 
Happily, governments have expressed commitments on numerous occasions to work towards avoiding conflicts between actions taken pursuant to MEAs and to the WTO, and to work towards making trade liberalization and environmental protection mutually supportive. In its first decision, the WTO Appellate Body took note that in the Preamble to the WTO Agreement and in the WTO Decision on Trade and Environment "... there is specific acknowledgement to be found about the importance of coordinating policies on trade and the environment". ${ }^{141}$ Over the past several years, many organizations have undertaken initiatives seeking to head off conflicts between the trade and biosafety regimes. The first to do so was the OECD which undertook joint efforts by its environment and trade directorates. ${ }^{142}$

Too often in the past, environmentalists thinking about the WTO have adopted a defensive mindset and have focused on how environmental measures might be permitted or excused under WTO rules. A key lesson from 17 years of the trade and environment debate is that environmentalists should be more proactive in thinking about how the rules and influence of the WTO can be harnessed in favor of environmental protection and sustainable development. In a globalized world, the WTO can no longer be (if it ever was) merely a trade agency. The WTO also has to be an environment agency.

A recent statement by the WTO Secretariat crystallized the existence of the policy choice. In its pamphlet entitled "Trade and Environment at the WTO", ${ }^{143}$ the WTO Secretariat declares that one of the "parameters". for WTO discussion of trade and environment is that the "WTO is not an Environmental Protection Agency." 144 The Secretariat may be right that such a proposition underlies current thinking inside the WTO. Nevertheless, as a normative proposition, this view is ill-considered. In some ways, today's WTO is already an environmental agency and is becoming more of one. ${ }^{145}$

In positing the WTO as an environmental agency, this article is not suggesting that such a descriptor is the best one for the WTO. The beginning of wisdom is to recognize that the WTO is multifunctional. It is primarily a trade liberalization agency, but also plays an overlapping role in many regimes. As noted in the 2003 Declaration of the Parliamentary Conference on the WTO, the "WTO is rapidly becoming more than a mere trade organisation". ${ }^{146}$

Besides being a trade liberalization agency, the WTO has taken on additional identities. The WTO is an agriculture agency that addresses food aid. ${ }^{147}$ Through TRIPS, the WTO has certainly become an intellectual property agency. ${ }^{148}$ Since the Dolia Ministerial Conference of 2001, the WTO has become a development agency too. ${ }^{149}$

141 United States-Standards for Reformulated and Conventional Gasoline (1996), WTO Doc. WTO/DS2/AB/R at 30 (Appcllatc Body Report).

142 In WTO circles, the OECD is sometimes referred to derisively as the Organization for Endless Conversation and Discussion. Yet in recent years, the WTO has looked more like a world talk organization than a trade negotiating forum.

143 Online: WTO <http://www,wto.org/english/tratop_e/envir_e/envir_wto2004_c.pdf>.

144 Supra note 38 at 6

145 The proposition that the WTO is an environment agency could be stated another way-namely, that certain WTO rules are part of international environmental law. Several years ago, a compendium of international environmental law, produced for Dutch universities, listed some trade law (see J.G. Lammers, Internationaal Milieurecht (The Hague: T.M.C. Asser Instituut, 1995) at 235).

146 Online: IPU < http://www.ipu,org/splz-c/trade03.htm> at para. 8.

147 Ruosi Zhang, "Food Security: Food Trade Regime and Food Aid Regime" (2004) 7(3) J. Int'l Econ. L. 565.

148 Some analysts argue that this extraneous role is a bad idea. See, e.g., Jagdish Bhagiwati, (2004) In Defense of Globalization (Oxford: Oxford University Press, 2004) at 182-18.5.

${ }^{149}$ But see the WTO Sutherland Commission report which asserts that "While trade is an important factor in achieving development aims, the WTO is not a development agency" (Peter Sutherland et al., The Future of the WTO. Report by the Consultative Board to the Director-General Supachai Panitchiakdi (Geneva: WrO, 2005) at para. 269). 
As an environment agency, the WTO is situated within the dense galaxy of international environment agencies. Indeed, the fragmented nature of environmental governance has become a serious problem, and one in need of organizational reform. ${ }^{150}$ Besides the WTO, the World Bank is another major multifunctional agency pursuing an environmental mission.

A greener vision of the WTO would be objected to by many. Some analysts propound the view that the WTO should be only an agency that facilitates exchange for market access. The economist Robert Staiger has taken that position in his thoughtful scholarship on the WTO. Staiger would be the first to acknowledge that the WTO of today has strayed from that singular mission and he recommends disentangling trade from other issues and refocusing it on "securing market access property rights". ${ }^{151}$

Yet if the WTO is to be exclusively a market access rights agency, aloof from the environment regime, then that separate positioning would facilitate the erroneous view that trade law is hierarchically superior to environmental law. ${ }^{152}$ The danger in allowing the WTO to view itself as outside the environment regime is that the WTO can just say "no" to a national environment or public health measure without taking any responsibility for the repercussions of its decision and, when warranted, getting the disputing parties to a cooperative "yes". International governance will suffer a pathology when negative integration decisions can be taken in one international organization without any connection to whether positive integration decisions are taken in a parallel organization.

For 25 years, the paradigm for how the trading system interacts with environment (and other "nontrade" issues) has been "linkage". ${ }^{153}$ Analysts have focused on the policy tensions that develop when the trade regime pursuing its own objectives crosses paths with the environment regime pursuing its own objectives. The underlying assumption in the linkage paradigm is that the trading system is about trade, not the environment, and so environmental claims can only enter via a linkage. Yet for many governments and stakeholders in the trade community, "linkage" is a dirty word, and not gaining in popularity.

The time has come to think outside the linkage box. In 1992, Agenda 21 stated that the "international community should: ... (d) Ensure that environment and trade policies are mutually supportive, with a view to achieving sustainable development." 154 This notion of mutual supportiveness has been repeated in other intergovernmental conventions ${ }^{155}$ and declarations and yet, even 15 years later, governments have not made much progress in thinking through what it means for trade policy to be mutually supportive with environmental policy (and vice versa).

The remainder of Part IV presents a new paradigm for reconceptualizing the WTO's role with respect to the environment. The existing paradigm is trade linkage which considers how an organization with a trade purpose should deal with nontrade objectives, such as biosafety. The new paradigm is to see the WTO as an organization with multiple objectives, including, for example, pollution control, biodiversity, and public health.

150 Konrad von Moltke, "Clustering International Environmental Agreements as an Alternative to World Environment Organization" in Frank Biermann and Stephen Bauer eds., A World Environment Organization. Solution or Threat for Effective International Environmental Governance (Aldershot, U.K.: Ashgate, 2005) 175.

151 Robert W Staiger, Report on the International Trade Regime for the International Task Force on Global Public Goods, online: International Task Force on Global Public Goods <http://www.gpgtaskforce.org/ uplonds/files/41.pdf> at 13.

152 The same point about trade supremacy can be made with respect to the human rights regime as there too the WTO has sometimes imagined itself as higher law (Joost Pauwelyn, "WTO Compassion or Superiority Complex? What to Make of the WTO Waiver for "Conflict Dianonds"' (2003) 24 Mich. J. Int'l L 1177; Daniel Pruzin, "U.N. Human Rights Official Warns Against WTO Restrictions on Food Aid", BNA Daily Report for Executives (20 July 2005).

153 See José E. Alvarez, “The WTO as Linkage Machine” (2002) 96(1) Am. J. Int'l L. 146.

154 Agenda 2I (1992), online: United Nations <http://www.un.org/csa/sustdev/documents/agend.21/english/ genda2 1 toc.hem> at para. 2.10(d).

155 Including the Preamble to the Cartagena Protocol. 
Viewing agencies as multifunctional is in tension with a controversial decision of the International Court of Justice (ICJ). In 1996, the ICJ decided that it could not respond to a request by the World Health Organization (WHO) for an advisory opinion regarding the legality of the use by a state of nuclear weapons in armed conflict (International Court of Justice, 1996)..$^{156}$ The Court pointed to two reasons why the WHO lacked authority to pose that question: (1) the "general principle of speciality" and (2) the logic of the overall system contemplated by the U.N. Charter. ${ }^{157}$ On the same day that it turned down the WHO, the Court issued an advisory opinion on a similar question requested by the U.N. General Assembly.

With regard to the first reason for turning down the WHO, the Court held:

International organizations are governed by the "principle of speciality", that is to say, they are invested by the States which create them with powers, the limits of which are a function of the common interests whose promotion those States entrust to them. ${ }^{158}$

The Court further explained that, although the powers conferred on international organizations are normally the subject of an express statement in their constituent instruments, "the necessities of international life may point the need for organizations, in order to achieve their objectives, to possess subsidiary powers which are not expressly provided for in the basic instruments which govern their activities." 159

How does the international law "principle of speciality" rclate to the environment? The environmental and market interdependencies of life on Earth makes it hard to slice up distinct roles for environmental and non-environmental agencies, or health and non-health agencies. Eventually, the bureaucratic preference for functional compartmentalization has to give way to ecological, economic, and political realities. That need for coherence, too, is one of the necessities of international life.

\section{Achieving an Environmentally Sound WTO}

Perhaps the governments drafting the WTO Agreement originally intended to create a tradespecific agency, but by the time the negotiations were completed in 1994, the Preamble to the WTO Agreement embraced sustainable development and the environment as a common interest. Then in 1998, the Appellate Body breathed life into the Preamble language. In 2001, at the Doha Ministerial, the necessities of international life pointed to a need to launch new negotiations on "trade and environment". Several years later, the Doha Round flounders. But the environmental agenda of the Round is hardly the problem.

Maintaining a trade-only identity for the WTO proved impossible because various nontrade issues, such as intellectual property, had already crept into the mission of the trading system. Unlike intellectual property, however, where there existed a World Intellectual Property Organization fully competent in the field, for the environment, there is no World Environment Organization with competence for major environmental issues. ${ }^{160}$ Thus, if the mandate of an international organization is driven by speciality and a rational division of

156 Legality of the Use by a State of Nuclear Weapons in Armed Conflict (1996), Advisory Opinion, [1996] I.C.J. Rep. 226, online: International Court of Justice <http://www.icj-cij.org/icjwww/idecisions.htm>. The Court's holding is criticized in the dissenting opinions and in scholarly commentary. For exanuple, sce the essays by Pierre Klein, Michael Bothe, and Virginia Leary in: Boisson de Chazournes and Sands eds., 1999; sec also the discussion in Burci and Vignes, 2004: 114-118. Boisson de Chazournes, Laurence \& Philippe Sands eds., International Law, the International Court of Justice and Nuclear Weapons (Cambridge: Cambridge University Press, 1999); Gian Luca Burci \& Claude-Henri Vignes, World Health Orgranization (The Haguc: Kluwer Law International, 2004).

157 Legality, ibid. at para. 26.

158 Ibid. at para. 25.

159 Ibid. at para. 25.

160) James Gustave Speth, Red Sky at Morning (New Laven, CT: Yale University Press, 2004) at 177. 
labour, then the absence of a World Environment Organization provides more justification for a WTO role on the environment than is justified for intellectual property. ${ }^{161}$

In envisioning the WTO an environment agency, I am not suggesting that specialization has become obsolete. Even in today's interconnected world, many international agencies should remain highly specialized because that is often the best way to get things done. What I am saying is that policymakers should move beyond the constructs of the past that view the functional international organization as unitary in purpose. Instead, one should anticipate that major international organizations will often have multifunctional roles that may not always reflect full agreement among state members regarding the common purposes and interests that underlie the organization. Internal organizational complexity and divergence are to be expected. ${ }^{162}$ With member states each having multiple policy objectives, and with differing policy chromatograms for each state, it seems unreasonable to imagine that those same states will typically put aside their differences to create uni-function international agencies.

Acknowledging the WTO as an environment agency should become the new paradigm for integrating trade and environment. Staying with the old paradigm of linkage will frustrate a reconciliation of environment and trade objectives. In linkage, trade and environment are seen as substitutes. Thus, many national representatives to the WTO dislike that environment is now a WTO issue because they view it as disguised protection. Ironically, most protectionism carried out under the aegis of the WTO is undisguised. Governments are permitted, and even encouraged (see GATT Article XVIII), to use tariffs to gain a trade advantage. For higher income countries, like the United States, the protective instrument of choice is the subsidy, for example, to agriculture.

Instead of viewing trade and environment as substitutes, the WTO should view them as complements. The new consciousness should be that environment and sustainable development are part of the purpose of the WTO, not just a rhetorical adornment. WTO Director-General Pascal Lamy stated this well in a recent speech: "We must remember that sustainable development is itself the end-goal of this institution." ${ }^{63} \mathrm{He}$ went on to say that "accompanying" social and environmental policies "... can no longer be looked at by the WTO as the responsibility of other organizations. The WTO is responsible for them too." 164

One strategy to improve performance of international organizations, such as the WTO, is to promote competition. To assist the WTO to being more successful, the major environmental entities, like the Biodiversity regime, should seek to hold the WTO accountable. In particular, these entities should evaluate the WTO on its environmental achievements and its shortcomings. Furthermore, environmental agencies should work to internalize their norms into WTO processes. Environment ministers should reflect on the fact that the trade community is not shy about insinuating its norms into environment treaties. This happened, for example, in the Cartagena Protocol and in the 1997 amendments to the International Plant Protection Convention (art. XVI). ${ }^{165}$

161 For a contrary view, see Keith E. Maskus, "Regulatory Standards in the WTO: Comparing Intellectual Property Rights with Competition Policy, Environmental Protection, and Core Labor Standards" (2002) 1(2) World Trade Revicu 135.

162 Coicaud, Jean-Marc, "International Organizations, the Evolution of International Politics, and Legitimacy" in Jean-Marc Coicaud \& Veijo Heiskanen eds., The Legitimacy of International Organizations (Tokyo: U.N. University Press, 2001) 519 at 524-525.

163 Pascal Lamy, "Trade Can Be A Friend, and Not a Foe, of Conservation" (Address to WTO Symposium, October 2005), online: WTO <http://www.wto.org/english/news_e/sppl_e/sppl07_e.htm>.

164 Ibid. For a similar point, see Moisés Naín, “The Free Trade Paradox" (2007) Foreign Policy, Sept./Oct. 2007, 95-96 ("No country acting alone stands as good a chance of monitoring and curtailing such lethal goods [e.g., deadly dog food and toxic toothpaste from Chinal as does the WTO working in concert with governments across the globe.").

165 Supra note 65. 
Another way that environment agencies might help the trading system is by seeking to transplant their scientific orientation into the WTO. The WTO needs outside influence to convince it to make sure that all of its trade rules have a scientific basis. Take antidumping investigations for example. The IWTO actually requires governments to perform such investigations, ${ }^{166}$ and the WTO Secretariat has been generous in delivering technical assistance to developing countries to get their antidumping programmes into action. Yet there is no scientific basis for the notion that countries can boost their national income by imposing tariffs to stop the importation of low-price, "dumped" goods. ${ }^{167}$ To be sure, an antidumping programme can effectuate a redistributional objective within a country. But there are less trade-restrictive ways to accomplish that objective than blocking anti-inflationary imports.

\section{CONCLUSION}

The WTO Secretariat contends that "The WTO is not an environmental protection agency", 168 and that statement provides a good window into understanding why the WTO has underachieved on the environment. As this article shows, the WTO is already an environmental agency in some of its treaty provisions and in its pro-environmental negotiating agenda. Notably, this agenda includes increasing market access for environmental goods and services and curtailing government subsidies that lead to overfishing.

Why then does the Secretariat deny the WTO's environmental identity? It is because the WTO wants the power to tell governments what measures they cannot use for the environment, but the WTO wants to avoid any environmental responsibilities. Instead, the WTO wants to leave to national and international environment agencies the hard work of formulating strategies to address environmental problems, and, on transborder threats, getting governments to agree. In view of the disorganization and weak nature of international environmental governance, there is a clear danger in giving the WTO power over the use of environmental measures without any responsibility for achieving environmental outcomes. Reform can come through inculcating a greater sense of environmental responsibility into the WTO. By calling it an environment agency, one can challenge it to be more accountable to the public and the planet.

Today, the WTO operates as an environmental agency, and yet performs that task poorly. It allowed the Doha Round to drag on despite the importance of trade liberalization for reducing world poverty. It made all environmental technology subsidies potentially actionable. It has neglected to do environmental assessments of proposals in the Doha Round negotiations. It has failed to make appropriate arrangements for effective cooperation with international environmental agencies. Its emerging caselaw may threaten to reduce legitimate environmental regulatory authority.

Fixing these problems will not be easy. For decades ago in her majestic Spaceship Earth, Barbara Ward pondered reaching a time when we "realize the moral unity of our human experience and make it the basis of a patriotism for the world itself". ${ }^{169}$ Attention to the world's ecological needs ought to be a hallmark of a world trade organization. Looking ahead a decade or two, one can hope that the WTO will not only become a better environmental agency, but will also be happy to admit it.

\footnotetext{
166 Supra note 7, art. VI, Antidumping Agreement, art. 5.1.

167 Douglas A. Irwin, Free Trade Under Fire ('Princeton: Princeton University P'ress. 2002) at 124-128.

168 Supra note 38 at 6.

169 Barbara Ward, Spaceship, Earth (New York: Columbia University Press, 1966) at 148.
} 